Годишњак Филозофског факултета у Новом Саду, Књига ХХХІХ-1 (2014)

Annual Review of the Faculty of Philosophy, Novi Sad, Volume XXXIX-1 (2014)

Jasmina Pekić

Filozofski fakultet Univerziteta u Novom Sadu

UDK: $159.928: 378$

Originalan naučni rad

\title{
AKADEMSKA DAROVITOST: POJAVNI OBLICI I EMPIRIJSKA POZADINA ${ }^{1}$
}

Rad pojašnjava fenomen akademske darovitosti u terminima njenih pojavnih formi, naglašavajući da se izuzetne sposobnosti ovladavanja novim informacijama vezuju za konkretno područje znanja, premda ne treba prevideti ni mogućnost da akademska darovitost u osnovi ima visok potencijal koji se registruje u širokom rasponu nastavnih oblasti. U radu se daje pregled nalaza istraživanja akademske darovitosti koji pretenduju da bliže pojasne njene ključne konstituente: specifične sposobnosti, intrinzičku motivaciju i kreativnost. Posebna pažnja je posvećena diskusiji nalaza koji nude oprečna viđenja uloge kreativnosti u dostizanju akademske izvrsnosti, pri čemu se naposletku izvodi zaključak da se akademski talenat u najvećoj meri svodi na prilagođavanje postojećim školskim zahtevima, ali da akademski domeni iziskuju i izvestan stepen divergentosti u mišljenju, koja potpomaže ovladavanje školskim zahtevima.

Ključne reči: akademska darovitost, kognitivni aspekt akademske darovitosti, intrinzička motivacija, kreativnost.

Domen specifičnih akademskih sposobnosti predstavljao je jedno od prvih socijalno relevantnih područja širenja koncepta darovitosti, a reputacija problematike darovitosti u koju se investira, zasigurno, najviše naučnih napora, prati ga i do danas. Sam pojam akademske darovitosti neretko se upotrebljava u prilično širokom značenju i susreće se u okviru često naznačavane dihotomije akademska/ neakademska darovitost, koja implicira da se prvi tip odnosi na izvrsnost u jednom ili više akademskih subdomena (nastavnih predmeta) koji podrazumevaju visoku opštu inteligenciju (matematika, jezik, naučne discipline), dok se neakademska darovitost vezuje za oblasti u kojima je zapaženi učinak moguć i u odsustvu visokih vrednosti kvocijenta inteligencije (muzika, umetnost, sport) (Gray-Fow, 2005; Winner, 1996; Winner \& Martino, 2000). Preciznije definicije akademskog talenta tumače ga kao sposobnost lakog ovladavanja nastavnim sadržajima, koja se manifestuje kao uspeh u rešavanju testova znanja i izvršavanju školskih zadataka (Renzulli, 1986, prema Kerr, 2009; Renzulli, 2005), ili naprosto kao izuzetnu sposobnost za usvajanje i sintetizovanje novih znanja (Callahan \& Miller, 2005).

jpekic@ff.uns.ac.rs 
Pomenuta klasifikacija domena darovitosti inicirala je kontroverznu terminološku distinkciju između ,darovitosti“ i „,talenta“, pri čemu se prvi termin vezivao za visoke domete $u$ naučnim disciplinama, dok je naprednost $u$ muzici, umetnosti i sportu etiketirana kao ,talenat“. S obzirom na to da su ovakva stremljenja protumačena kao implicitno i neosnovano degradiranje „neakademskih“ vidova darovitosti, sugerišući da su svi talenti ,jednaki, ali da su neki jednakiji“, većina autora termine „darovitost" $\mathrm{i}$,talenat" upotrebljava kao sinonime. Najubedljivijim argumentom terminološkog i vrednosnog izjednačavanja izvrsnosti u akademskim i neakademskim domenima, može se smatrati shvatanje o univerzalnim karakteristikama darovite dece. Naime, Vinerova (Winner, 1996; Winner \& Martino, 2000) ističe da sva darovita deca, bez obzira na domen ka kome upravljaju svoj izuzetni potencijal, manifestuju složaj triju personalnih karakteristika: naprednost (vrlo rano ispoljavanje visokih sposobnosti), žudnja za ovladavanjem određenim domenom (intrinzička motivacija za usvajanjem novih znanja, „opsesivna“ zainteresovanost za dati domen) i nezavisnost u mišljenju i delovanju (rešavanje problema na neobičan, idiosinkratski način, samostalno ovladavanje domenom darovitosti uz minimalnu pomoć odraslih osoba). Prema tome, ova univerzalna obeležja darovitosti mogu se protumačiti kao signal o postojanju svojevrsnog 'konstitutivnog jezgra' ovog konstrukta, koje je postojano u dodiru sa sadržajem različitih domena darovitosti, zbog čega je neosnovano pretpostaviti da se akademski i neakademski vidovi talenta suštinski razlikuju, te da je ovu razliku neophodno potencirati i na terminološkom planu ${ }^{2}$.

\section{OBLICI AKADEMSKOG TALENTA}

Globalna akademska darovitost. Termanova monumentalna Genetička studija genijalnosti pominje se i kao prvi sistematski prilaz u empirijskom izučavanju akademske darovitosti, usled saznanja o značajnoj povezanosti visoke opšte inteligencije sa izuzetnim akademskim učinkom (Winner, 1996). Premda je pomenuta studija pretrpela ozbiljna preispitivanja svojih bazičnih postavki i zadobila reputaciju antipoda „liberalnog“ konceptualizovanja darovitosti, njena redukovanost na okvire opšte inteligencije pokazala se celishodnom za svrhu pojašnjenja retkih, ali višestruko zabeleženih slučajeva akademskog talenta. Naime, iako se teza o globalnoj darovitosti u savremenoj literturi kotira kao mit, slučajevi dece koja poseduju opštu predispoziciju za širok raspon akademskih subdomena, odnosno nastavnih predmeta, te ostvaruju natprosečan učinak na raznolikim zadacima $u$ okviru testova inteligencije, nesumnjivo upućuju na postojanje akademske daro-

I u ovom radu se termini „,darovitost“ $\mathrm{i}$ „talenat“ uporedo koriste. Osim argumenata koje iznosi Vinerova, dodatni razlog zbog kojeg se ravnopravan terminološki status ovih pojmova čini opravdanim predstavlja podatak o postojanju još dva slučaja njihovog uzajamnog razlikovanja, što doprinosi još većoj terminološkoj konfuziji. Prvi slučaj se odnosi na izjednačavanje darovitosti sa prirodnim sposobnostima, a talenta sa sistematski razvijanim veštinama (Gagné 2000; Gagné, 2005), dok drugi slučaj podrazumeva upotrebu termina „darovitost“ u značenju opštijih sposobnosti, a „talenta“ u značenju sposobnosti u specifičnijim oblastima znanja (George, 1997; Robinson, 2005). 
vitosti globalnog tipa. Ova svestranost u aktualizaciji potencijala, na pojedinim mestima se tumači podjednakom lakoćom operisanja sa dva fundamentalna sistema simbola koji predstavljaju ključno oruđe formalnog obrazovanja, a to su jezički i numerički simboli (Winner, 1996). Drugim rečima, globalna akademska darovitost predstavlja sinonim za ujednačenost intelektualnog profila, koji beleži podjednaka povišenja u aspektu verbalnih i neverbalnih sposobnosti. Jedno novije istraživanje samoprecene razvijenosti različitih vidova inteligencije u skupini darovitih učenika, pokazalo je da je izvestan broj ispitanika svoj kognitivni profil opisao u terminima globalne darovitosti (Chan, 2008).

$\mathrm{Na}$ pojavnom planu, ovaj tip akademskog talenta podrazumeva podjednaku prijemčivost za domene darovitosti koji korespondiraju sa nastavnim predmetma u okviru formalnih obrazovnih sistema, a koji se po jednoj klasifikaciji dele na „fundamentalne domene“ i ,domene performanse" (Cross \& Coleman, 2005). Naime, većina nastavnih predmeta predstavlja osnovu kasnijeg ovladavanja domenima „koji funkcionišu izvan školskih okvira“ (Cross \& Coleman, 2005, str. 57), te su označeni izrazom fundamentalni akademski domeni. Tako na primer, matematika predstavlja osnovu za ovladavanje domenom arhitekture, predmeti iz oblasti prirodnih nauka pripremaju učenike za domen medicine itd. Sa druge strane, domeni performanse sadrže znanja koja su imanentna samo tim domenima (self-contained domains), što znači da nisu koncipirani kao osnova na koju se nadograđuju saznanja iz drugih, kasnije dostupnih oblasti. U našem (srednjoškolskom) obrazovnom sistemu, to bi bili predmeti poput sociologije, filozofije, psihologije i sl. Naziv ove kategorije akademskih subdomena potiče otuda što se izvrsnost u okviru njih procenjuje isključivo preko testova znanja, koji mere ,performansu“, dok se darovitost u fundamentalnim domenima može procenjivati i testovima sposobnosti i testovima znanja. Prema tome, globalna akademska darovitost može biti predstavljena i kao podjednaka lakoća u ovladavanju bazičnim i „sui generis“" područjima znanja. Ovu kategoriju učenika literatura označava i izrazom „svestrano daroviti““ (all-rounders) (Gray-Fow, 2005).

O globalnoj akademskoj darovitosti moguće je govoriti i kao o fenomenu multiplih talenata (Gross, 2005). No, praktičari neretko ispoljavaju sklonost ka fokusiranju na samo jedan, dominantni tip talenta, zanemarujući učenikove naprednosti u ostalim akademskim domenima. Ovo previđanje raznolikosti akademskih potencijala u obrazovnoj praksi zapadnih zemalja može predstavljati posledicu enormne popularnosti i nekritičke prihvaćenosti Gardnerovog koncepta multiplih inteligencija (Gross, 2005). Naime, u izvornoj verziji svoje teorije, Gardner postulira sedam tipova inteligencije: lingvistička, logičko-matematička, muzička, prostorna, telesno-kinestetička, interpersonalna i intrapersonalana inteligencija (Gardner, 1993) ${ }^{3}$. Premda su koncipirane kao relativno nezavisne forme intelektualnog postignuća, „multiple inteligincije“ nipošto ne podrazumevaju „čistu

U kasnijim revizijama ove teorije, Gardner uvodi i tzv. naturalističku inteligenciju kao osmi tip, dok egstinencijalnoj i spiritualnoj inteligenciji dodeljuje status kandidata za inkluziju u postojeći teorijski model (Gardner, 1999, prema Ziegler \& Heller, 2000). 
kognitivnu esenciju“ (Gardner, 1999, prema Gross, 2005, str. 115), zbog čega je Gardner oštro kritikovao primenu ovih koncepata kao predložaka za identifikaciju darovitih učenika (Gardner, 1999, prema Gross, 2005). Dakle, čak i sa stanovišta jedne od najpoznatijih savremenih antiteza konceptu globalne inteligencije, darovitost može ispoljavati opštiji karakter, objedinjujući izvrsnost u širem opsegu intelektualnih sposobnosti.

Domenospecifična akademska darovitost. Diskrepanca u nivou razvijenosti različitih aspekata inteligencije predstavlja znatno uobičajeniju kognitivnu podlogu akademske darovitosti. Naime, u velikom broju istraživanja intelektualnog profila akademski darovitih, ustanovljene su mnogo niže interkorelacije skorova na pojedinačnim subtestovima inteligencije, nego u slučaju ispitanika kontrolne skupine (Benbow \& Minor, 1990; Lewis, 1985; Silver \& Clampit, 1990). Drugim rečima, što je kvocijent inteligencije viši, to je disparitet među specifičnim intelektualnim sposobnostima naglašeniji (Detterman \& Daniel, 1989). Potvrdu ovih zapažanja nude $\mathrm{i}$ istraživanja inteligencije darovite dece pomoću Vekslerove baterije testova inteligencije, u kojima je ustanovljena pozitivna korelacija između visine globalnog kvocijenta inteligencije i veličine diskrepance između verbalnog i manipulativnog kvocijenta inteligencije (Detterman \& Daniel, 1989; Legree, Pifer, \& Grafton, 1996; Sweetland, Reina \& Tatti, 2006; Wilkinson, 1993). U terminima pojavnih formi ovog tipa akademskog talenta, neujednačenost intelektualnog profila znači da se daroviti učenici najčešće prepoznaju u pojedinačnim oblastima znanja, odnosno da imaju ,jake i slabije tačke“ kad je reč o različitim nastavnim predmetima, ili, kako neki autori ekspliciraju, ,,jedinstvenu kombinaciju izuzetnih postignuća, sposobnosti ili talenata" (Achter, Lubinski \& Benbow, 1996, prema Feldhusen \& Jarwan, 2000, str. 274). Na pojedinim mestima u literaturi se navodi da se akademski daroviti učenici najlakše prepoznaju u domenima matematike i jezika, otuda što su ovi domeni „formalni i visoko strukturirani“, što, zapravo, znači da u njima postoje eksplicitna pravila prepoznavanja izvrsnosti koja jasno ukazuju na količinu i vrstu sadržaja kojima učenik treba da ovlada kako bi u ovim domenima bio prepoznat kao darovit (Winner, 1996). No, najvećoj transparentnosti matematičkog i lingvističkog talenta, zasigurno, doprinosi i činjenica da se ovi tipovi darovitosti i najviše favorizuju u okviru tradicionalno ustrojenih obrazovnih sistema (Gardner, 1993).

Jedan od najuticajnih modela strukture matematičkog talenta koji se učestano pominje u savremenoj literaturi o ovoj problematici, ovaj fenomen kvalifikuje kao „distinktivni sindrom“ koji udružuje sposobnosti iz tri krucijalna aspekta, a to su prijem, obrada i retencija matematičkih informacija (Krutetskii, 1976, prema Wieczerkowsky, Cropley \& Prado, 2000). Prema viđenju Kruteckog, matematički talenat ne podrazumeva samo viši stepen razvijenosti specifičnih intelektualnih sposobnosti, na koje su se pozivali psihometrijski orijentisani izučavaoci ove problematike (kao npr. Mekobi i Džeklin koji osnovnim sastojkom matematičkog talenta proglašavaju numeričke sposobnosti, vizuo-spacijalne sposobnosti i sposobnosti logičkog rezonovanja (Macoby \& Jacklin, 1974)), već kvalitativno druga- 
čiji način kognitivnog funkcionisanja. Insistirajući, dakle, na matematičkom talentu kao distinktivnom sindromu viševrsnih matematičkih sposobnosti, ovaj autor uvodi koncept „matematičkog tipa uma“ (the mathematical cast of mind), koji u priličnoj meri korespondira sa nalazima da matematički daroviti učenici matematiku percipiraju kao domen koji iziskuje „,poseban način mišljenja“ (Burton, 1984). Krutecki je, nadalje, naznačio i distinkciju između ,akademskog“ i ,kreativnog“ matematičkog talenta (Krutetskii, 1976, prema Livne \& Milgram, 2000) i premda se nije upuštao u detaljnije empirijske razrade ovih koncepata, oni su ostvarili potvrdu u istraživanjima drugih autora. Naime, pojedina mesta u literaturi nude nalaze o postojanju barem dva tipa matematički darovitih učenika - učenici čija se darovitost manifestuje kao ovladanost strategijama rešavanja problema koje se, po pravilu, uče na znatno kasnijim uzrastima, i učenici koji se smatraju darovitim usled sklonosti ka rešavanju matematičkih problema na vlastiti način, bitno drugačiji od naučenih strategija rešavanja (Sowell et al., 1990, prema Reed, 2004). Nalaze koji sugerišu osnovanost razlikovanja akademskog i kreativnog talenta susrećemo i kod mnogih drugih autora (vidi npr. Root-Bernstein, Bernstein \& Gamier, 1995; Shavina \& Kholodnaja, 1996; Span \& Overtoom-Corsmith, 1986). Tendencija razlikovanja pojavnih formi visokih matematičkih sposobnosti, prisutna je i u nešto drugačijem obliku. Naime, pojedini autori naglašavaju da se matematički talenat, prvenstveno, manifestuje u visokoj sposobnosti matematičkog rezonovanja i generisanja novih ideja, a ne samo u umešnosti vršenja računskih operacija i reprodukovanja naučenih principa (Fox, 1981). U prvom slučaju, naime, reč je o ,istinskom matematičkom talentu“" (truly mathematical talent), a u drugom slučaju o učenicima koji (samo) ostvaruju visoko školsko postignuće iz matematike (high achievers in mathematics) (Miller, 1990), što je konstatovano i u domaćim istraživanjima strukture matematičkog talenta (Štula, 2007). Potonji način diferenciranja pojavnih formi matematičkog talenta mogao bi se dovesti u relaciju sa nalazima da se indikatori darovitosti u matematici javljaju na kasnijem uzrastu, nego indikatori verbalne darovitosti (Simonton, 1984). Naime, ako se istinski matematički talenat očituje u sposobnosti matematičkog rezonovanja i generisanja novih ideja, to bi onda podrazumevalo prethodnu ovladanost ,,apstraktnim i kompleksnim aspektima domena matematike", za koje je empirijski utvrđeno da su deci nedostupni pre desete godine (Feldman, 1986, prema Feldman, 1991). ${ }^{4}$

Verbalna (lingvistička) darovitost ima poznate psihometrijske odrednice u vidu koncepata verbalne sposobnosti, verbalne fluentnosti, verbalnog razumevanja i sl., koji počivaju u osnovi većine baterija za merenje testova inteligencije (Olszewski-Kubilius \& Whalen, 2000). Moderne teorije o strukturi inteligencije definišu je kao sposobnost jezičkog izražavanja i razumevanja jezika, ili prosto kao sposobnost korišćenja jezika (Gardner, 1993, prema Gardner, Kornhaber \& Wake 1999). Ova sposobnost pokriva nekoliko važnih aspekata: fonologiju (govorni glasovi), sintaksu (gramatika), semantiku (značenje) i pragmatiku (upotreba jezi-

Feldman uz ovakve nalaze navodi i primer čuvenog matematičara Gausa, koji je počeo sa konstrukcijom matematičkih dokaza „tek“ u desetoj godini . 
ka u različitim okruženjima) i u vrhunskom obliku je zastupljena, prvenstveno, kod pisaca i pesnika, ali i u populacijama novinara, advokata i pisaca reklama. Tumačenja ovog vida darovitosti, sa aspekta njenih pojavnih akademskih formi, izdvajaju dve oblasti u kojima visoke verbalne sposobnosti dobijaju prepoznatljiv izraz, a to su literarno i oratorsko umeće. Literarna darovitost može podrazumevati različite forme kreativnog pisanja (pismeni sastavi u nastavi maternjeg jezika), odnosno umešnost u sastavljanju tekstova koji imaju informativni karakter (naučni i novinarski članci). Sa druge strane, verbalna darovitost govorničkog tipa prevashodno dolazi do izražaja pri usmenom odgovaranju i diskusijama. Visoke verbalne sposobnosti počivaju i u osnovi lakog ovladavanja čitanjem, pisanjem i usmenim komuniciranjem na stranim jezicima (Olszewski-Kubilius \& Whalen, 2000), kao i znanjima iz oblasti biologije, društvenih i humanističkih nauka (Gustin \& Corrazo, 1994; Shea, Lubinski \& Benbow, 2001).

Domenospecifična akademska darovitost neretko se označava i izrazom akademski asinhronitet, koji se u najprostijem obliku ispoljava kao razvojna naprednost u okviru nastavnog predmeta koji odgovara domenu učenikovog talenta, te prosečan učinak u oblastima ostalih nastavnih predmeta (Akin, 2005). Tako, na primer, učenik može ispoljavati ovladanost domenom matematike koja priliči starijim uzrastima, $i$ istovremeno funkcionisati na kognitivnom nivou svojih vršnjaka $u$ okviru ostalih nastavnih predmeta. No, osim asinhronije koja se javlja u kontekstu različitih oblasti znanja, akademski talenat može pokazivati neujednačenost i u okviru pojedinačnih nastavnih predmeta. Kao jednu od mogućih ilustracija ovog fenomena, pojedina mesta u literaturi opisuju slučajeve dece kod kojih se javlja raskorak u uspešnosti usmenog i pismenog izražavanja. Primera radi, učenik se može smatrati lingvistički darovitim u aspektu fluentnosti čitanja, bogatstva rečnika, te jasnoće i preciznosti u izražavanju misli, ali se, istovremeno, kod njega može uočiti problem $u$ aspektu bogatstva i orignalnosti pismene produkcije (Akin, 2005). Asinhronitet u razvoju verbalnih sposobnosti potvrđen je i nalazima koji svedoče o postojanju disbalansa između rane jezičke produkcije i razumevanja, sa jedne strane, i uspešnosti u ovladavanju veštinom čitanja, sa druge strane (Jackson \& Klein, 1997).

Šta se, naposletku, može zaključiti o različitim oblicima u kojima akademski talenat može da se pojavljuje? Premda se osnovno načelo savremnog određenja darovitosti može sažeti u zapažanje da ovaj konstrukt „moramo razmatrati ne samo u terminima multiplih komponenti, nego i u terminima njegovih različitih tipova“" (Sternberg, 1990, prema Heller \& Schofield, 2000, str. 123), važno je imati na umu i činjenicu da stvarnost ponekad oživljava mit o globalnoj darovitosti. Dakle, razvojni put izuzetnog potencijala najčešće podrazumeva njegovu jasnu diferencijaciju u kontekstu pojedinačnih područja znanja, no u pojedinim slučajevima akademska izvrsnost može ostati nespecifikovana, te podrazumevati darovitost u termanovskom smislu reči. Potonja mogućnost je, stoga, još jedan $\mathrm{u}$ nizu argumenata za valjanost primene kvocijenta inteligencije $\mathrm{u}$ identifikaciji akademske darovitosti. 


\section{ISTRAŽIVANJA AKADEMSKOG TALENTA}

Kognitivni aspekt. Bez obzira na razilaženja u shvatanjima najprimerenijeg načina identifikacije akademskog talenta, važnost opšte inteligencije u ostvarivanju visokih akademskih rezultata predstavlja mesto opšteg konsenzusa među različitim izučavaocima ove problematike. Naime, potvrdu zasnovanosti akademske darovitosti na visokim opštim intelektualnim potencijalima nalazimo u podacima da intelektualno nadprosečni učenici u najvećem broju slučajeva imaju odličan školski uspeh (Benbow \& Minor, 1990; Coleman \& Cross, 2001; Renzu11 i \& Reis, 2000), te u zapažanjima sličnosti između problemskih zadataka u testovima inteligencije i tradicionalnih školskih situacija (Renzulli \& Reis 2000; Salvia \& Ysseldyke, 1995). No, osim visoke opšte inteligencije, važna obeležja akademskog talenta naznačavana su i u mnogim drugim aspektima kognitivnog funkcionisanja darovitih učenika.

Kognitivna priroda akademskog talenta neretko je utvrđivana u istraživanjima koja su poredila akademski darovite i prosečne učenike. Ovakva poređenja su ukazala na postojanje određenih distinktivnih obeležja akademske darovitosti koje se ne tiču samo nejednakih dometa u razvijenosti sposobnosti ovih dveju skupina ispitanika, nego i kvaliteta njihovog (meta)kognitvnog funkcionisanja. Naime, nalazi ovih istraživanja su pokazali da akademski daroviti učenici imaju bolju kontrolu nad misaonim procesima prilikom rešavanja problema (Shore \& Carey, 1984, prema Hong \& Aqui, 2004), da koriste više strategija za organizovanje i transformisanje novih informacija (Zimmerman \& Martinez-Pons, 1990, prema Hong \& Aqui, 2004), da poseduju efikasnije strategije učenja, koje su, pri tom, lako prenosive na nove zadatke (Risemberg \& Zimmerman, 1992, prema Hong \& Aqui, 2004), te da su uspešniji u usvajanju, retenciji i primeni novih informacija (Sternberg, 1981, prema Gross, 2000).

Analiza akademskog talenta obavljala se i na području različitih školskih sposobnosti. Naime, na pojedinim mestima u literaturi se navodi da akademski daroviti učenici najlakše ovladavaju nastavnim predmetima koji iziskuju verbalne sposobnosti i apstraktno rezonovanje, dok su sadržaji predmeta koji favorizuju praktične veštine retko usaglašeni sa preferencijama darovitih učenika (Coleman \& Cross, 2001). Tipičan sholastički profil darovitog učenika ukazuje na prisustvo sledećih karakteristika: lako usvajanje novih informacija, obiman fond opštih znanja, bogat rečnik, raznolika interesovanja, razvijene čitalačke navike, napredno logičko mišljenje, lakoća u otkrivanju kauzalnih relacija, razvijena sposobnost zapažanja (Renzulli, Hartman \& Callahan, 1971, prema Coleman \& Cross, 2001). U nekim drugim istraživanjima ove vrste, visoka akademska postignuća se dovode $u$ vezu sa nesvakidašnjom radoznalošću i zainteresovanošću za raznovrsne naučne teme (Filippeli \& Walberg, 1997, prema Koro-Ljungberg, 2002), kao i sa sposobnošću razumevanja nastavnih sadržaja predviđenih za starije uzraste, zbog čega se o akademskom talentu govori i kao o pozitivnoj razlici između mentalnog i kalendarskog uzrasta, u nekim od akademskih subdomena (Brody \& Stanley, 
2005). Daroviti učenici, takođe, ispoljavaju sklonost ka postavljanju brojnih pitanja, kao i izraženu sposobnost samostalnog učenja, odnosno učenja na osnovu posmatranja drugih (Bloom, 1982, prema George, 2003).

No, osim opštih karakteristika akademskog talenta ustanovljenih u relaciji sa osrednjim školskim učinkom, daroviti učenici poseduju i specifična kvalitativna kognitivna obeležja koja korespondiraju sa područjima znanja za koja pokazuju najveće interesovanje. Naime, intelektualna struktura akademske darovitosti neretko je ispitivana uzajamnim poređenjem učenika darovitih u različitim akademskim subdomenima, u odnosu na njihov učinak na raznorodnim zadacima u okviru testova inteligencije. Imajući u vidu nalaze koji upućuju na postojanje najmanje dve forme akademskog talenta, od kojih je jedna verbalnog, a druga neverbalnog tipa (Benbow et al, 1983), specifična struktura akademskog talenta najčešće je utvrđivana poređenjem učenika darovitih u domenu jezika, sa matematički darovitim učenicima (Benbow \& Minor, 1990). U jednom istraživanju te vrste, poređenje matematički i jezički darovitih učenika obavljeno je u odnosu na Terstonove ,primarne sposobnosti“", s tim što su numerički faktor (N) i faktor verbalne fluentnosti (W), kao opštepoznata differentia specifica ovih vrsta darovitosti, izostavljeni iz razmatranja i zamenjeni sposobnostima mehaničkog rezonovanja (mechanical comprehension) i jezičke ekspresije (mechanics of English expression). Shodno tome, dobijeni rezultati su sugerisali značajne razlike među dvema grupama ispitanika u svim naznačenim aspektima, s tim što su razlike u pogledu razvijenosti spacijalnih, memoričkih, perceptivnih, mehaničkih, te sposobnosti neverbalnog rezonovanja bile u korist grupe matematički darovitih pojedinaca, dok su se pojedinci daroviti u domenu jezika istakli u pogledu verbalnih sposobnosti i nivoa opštih znanja, te sposobnosti jezičke ekspresije (Benbow \& Minor, 1990).

$\mathrm{Na}$ značajnu povezanost matematičkih i spacijalnih sposobnosti upućuju i nalazi brojnih drugih istraživanja (Casey \& Brabeck, 1989; Casey, Winner, Brabeck \& Sullivan, 1990; D’Amico \& Kimura, 1987; Hermelin \& O'Connor, 1986), dok je ujednačena razvijenost verbalnih i vizuo-spacijalnih sposobnosti vrlo retka i sreće se kod jednog od tri tipa matematičkog talenta koje opisuje Krutecki (Kruteskii, 1976, prema Winner, 1996). Zbog značajnog upliva vizuo-spacijalnih sposobnosti u postignuće u „kvantitativnim domenima“, sa punim pravom se zaključuje da ovaj tip sposobnosti ,ima reputaciju jedne od najvažnijih dimenzija kognitivnog funkcionisanja u školskom kontekstu, zajedno sa verbalnim i numeričkim sposobnostima“ (Chan, 2010, str. 59). Preciznije rečeno, vuzuo-spacijalne sposobnosti počivaju u osnovi postignuća u domenu matematike i tehničkih nauka, dok je njihov doprinos u predikciji uspešnosti u domenima biologije, društvenih i humanističkih nauka zanemarljiv, otuda što verbalne sposobnosti ubedljivo odnose primat u ovim oblastima (Shea, Lubinski \& Benbow, 2001). Tome slično, ustanovljeno je da stupanj razvijenosti vizuo-spacijalnih i matematičkih sposobnosti predstavlja dobru osnovu za predviđanje uspešnosti u studiranju prirodnih i tehničkih nauka (Humphreys \& Lubinski, 1996, prema Pyryt, 2000). 
Istraživanje sprovedeno na preko hiljadu akademski darovitih učenika pribavilo je nalaze koji sugerišu da akademski talenat retko objedinjuje izvrsnost $\mathrm{u}$ domenima matematike i jezika, zbog značajne diskrepance u nivou razvijenosti matematičkih i jezičkih sposobnosti kod ove kategorije ispitanika (Achter, Lubinski $\&$ Benbow, 1996, prema Robinson, 2005). Tačnije, učenici daroviti u domenu jezika mogu ostvarivati visok učinak u domenu matematike, ali je obrnuta situacija znatno ređa (Benbow et al., 1983). Objašnjenje ovakve relacije između dveju najčešćih pojavnih formi akademskog talenta, proizilazi iz saznanja o mogućnosti upotrebe strategija verbalnog rezonovanja u rešavanju matematičkih problema, dok matematičke sposobnosti nisu transferabilne na domen jezika (Winner, 1996). Blumova retrospektivna studija razvoja matematičkog talenta nudi potvrdu mnogo veće specifičnosti akademskog talenta u slučaju preimućstva matematičkih u odnosu na verbalne sposobnosti, posredstvom nalaza da nijedan od ispitivanih matematičara nije ovladao veštinom čitanja pre polaska u školu, dok je, otprilike, trećina ovih ispitanika imala ozbiljnih poteškoća u čitanju (Bloom, 1985). S tim u vezi, mnogi autori zaključuju da darovitost u tzv. „kvantitativnim“ domenima podrazumeva mnogo manju izbalansiranost kognitivnog profila, nego što je to slučaj sa darovitošću u domenu jezika (Benbow \& Minor, 1990; Winner, 1996; Olszewski-Kubilius \& Whalen, 2000).

Kognitivna podloga matematičkog i lingvističkog talenta opisana je i u terminima procesuiranja informacija. U jednom istraživanju ove vrste, učenici daroviti u domenu matematike i jezika uzajamno su upoređivani u tri aspekta: tačnost upamćivanja informacija, tačnost u manipulisanju podacima u radnoj memoriji, te brzina aktiviranja podataka pohranjenih u dugotrajnoj memoriji (Dark \& Benbow, 1991 prema Olszewski-Kubilius \& Whalen, 2000). Naime, dvema pomenutim grupama ispitanika kratko su izlagane različite liste stimulusa (brojevi, reči, slova i lokacije predmeta), uz zahtev za naknadnom reprodukcijom ovih stimulusa, odnosno upamćivanjem pozicije različitih predmeta. Kao što se može i pretpostaviti, matematički talentovani pojedinci su ispoljili razvijeniju memoriju za brojeve, prostorne relacije i vizuelne stimuluse koji se ne mogu verbalno kodirati, dok su se lingvistički daroviti pokazili superiornijim u upamćivanju reči, ali ne i pojedinačnih grafema. $U$ istom istraživanju, matematičke sposobnosti su se pokazale povezanim i sa sporijim gubitkom informacija iz radne memorije, bez obzira da li se radilo o verbalno ili numerički kodiranim informacijama, dok je u slučaju lingvističkog talenta ustanovljen brži pristup verbalnim informacijama u dugoročnoj memoriji, posredstvom zadataka leksičke odluke (prepoznavanje niza slova kao smislene reči). Nalazi nekih ranijih istraživanja slične problematike sugerišu mogućnost predikcije razvijenosti „kvantitavnih sposobnosti“ na višim nivoima školovanja na osnovu tačnosti upamćivanja bojeva (Pucket \& Kausler, 1984, prema Winner, 1996), odnosno povezanost memorije za reči (ali ne i za slova) i učinka na verbalnim zadacima (Palmer, McLeod, Hunt \& Davidson, 1985, prema Winner, 1996). Osim toga, slična istraživanja su, takođe, ukazala na vezu između brzine aktiviranja verbalnih informacija $u$ dugoročnoj memoriji i razvijenosti 
psihometrijski definisanih verbalnih sposobnosti (Hunt, Frost \& Lunneborg, 1973, Hunt, Lunneborg \& Lewis, 1975, svi prema Winner, 1996). Na osnovu pozamašnog korpusa nalaza istraživanja procesuiranja informacija u skupini darovitih, ispravno je zaključiti da darovitost nipošto ne podrazumeva globalni memorijski potencijal, zbog čega se može reći da razvijenost memorijskih aspekata darovitih predstavlja funkciju vrste materijala koja se upamćuje i domena darovitosti (Winner, 1996).

Izvan okvira kognicije. Saobražavajući se modernim shvatanjima darovitosti kao multidimenzionalnog konstrukta, konstituisana je i druga važna linija istraživanja koja je pretendovala da utvrdi doprinos nekognitivnih činilaca u ostvarivanju zapaženog akademskog učinka. Kao što se već zdravom logikom može dokučiti, najvažnijom „nekognitivnom“ odrednicom akademskog talenta pokazale su se motivacione dispozicije ličnosti, čiji su presudan doprinos priznavali i mnogi eminentni stvaraoci, dovitljivo ističući da je genijalnost sazdana od „1\% inspiracije i 99\% perspiracije“ (Edison, 1932, prema Lens \& Rand, 2000, str. 193). Ništa manje dovitljiva je i opaska da su osnovni preduslovi visokog učinka u bilo kojoj oblasti tri faktora: „rad, rad i rad““ (Ericson, 1996, prema Gray-Fow, 2005, str. 23).

No, kvantitativne procene odnosa ,inspiracije“ $\mathrm{i}$,persipracije“ $u$ transformaciji izuzetnih potencijala, sa stanovišta empirije su značajno drugačije, barem kada je reč o školskom kontekstu. Naime, istraživanja prediktivnog doprinosa raznorodnih činilaca uspešnosti u akademskim domenima stavljaju težište na opšte intelektualne i specifične kognitivne sposobnosti, nudeći nalaze koji sugerišu da prosečna visina koeficijenata korelacije ove grupe predikora i kriterijumske varijable gravitira oko vrednosti od 0.40. (Benbow \& Arjmand, 1990, Birx, 1988, svi prema Trost, 2000). Motivacione dispozije ličnosti su, pak, ispoljile nešto slabiju povezanost koja se kretala u rasponu od 0.20-0.35 (McCoach, 2002; Uguroglu \& Walberg, 1979; Hansford \& Hattie, 1982, prema Trost, 2000). No, u nekim sličnim istraživanjima konstatovan je viši stupanj involviranosti ovih činilaca u akademsko postugnuće, pri čemu je utvrđeno da individualne razlike u intelektualnim sposobnostima objašnjavaju oko $66 \%$ varijanse školskog postignuća, dok motivacija pruža objašnjenje za oko 33\% varijacija u školskim rezultatima (Atkinson, 1974, prema Lens \& Rand, 2000).

Osim utvrđivanja intenziteta povezanosti motivacije i akademskog postignuća, istraživanja darovitih u ovom segmentu pokušavaju da rasvetle i prirodu motivacije kojoj daroviti pojedinci duguju svoj impresivni učinak. U to ime, ova istraživanja operišu različitim motivacionim konstruktima, koji za zajednički imenitelj imaju ukazivanje na larpurlartistički karakter motivacije darovitih. Naime, opšte je poznato da je superiorno ovladavanje određenim područjem znanja teško zamislivo bez učenja koje je motivisano interesom za znanje, te koje je, prema tome, samo sebi cilj. S tim u vezi, u literaturi se pominju nalazi koji sugerišu da ,žudnja za ovladavanjem" rezultira visokim učinkom otuda što podrazumeva opsesivnu zaokupljenost i striknu upravljenost na sadržaje određenog domena, koja neretko prerasta u svojevrsnu izopštenost iz spoljne stvarnosti (Winner, 1996; Winner \& Martino, 2000). Neki drugi autori ovaj oblik motivacije nazivaju „pasijom“, te 
empirijski potvrđuju postojanje njene „harmonične“ $i$ „opsesivne“ varijante (Vallerand \& Houlfort, 2003, prema Fredricks, Alfeld \& Eccles, 2010). Harmonična pasija se opisuje kao udubljenost $u$ aktivnosti ovladavanja određenim domenom nad kojom osoba ima kontrolu, dok se za opsesivnu formu pasije kaže da upravlja pojedincem i proizvodi osećanje krivice u slučaju upuštanja u aktivnosti koje nisu u funkciji sticanja relevantnih znanja. Otuda se harmonična pasija može proglasiti 'saveznikom' darovitosti, dok opsesivno stremljenje izvrsnosti može ispoljiti destruktivan uticaj na talenat. Pojedina mesta u literaturi intrinzičku motivaciju nazivaju „praplavljenošću“ (flow), opisujući je kao „stanje potpune predanosti u kojem osoba zanemaruje vreme, bazične potrebe i sve drugo izuzev same relevantne aktivnosti“" (Csikszentmihalyi, Abuhamdeh \& Nakamura, 2005, str. 600) U istraživanjima ,preplavljenosti“ na uzorku darovitih utvrđeno je da se ovaj oblik motivacije pokazao značajnim u predviđanju istrajnosti darovitih učenika u aktivnostima usvajanja znanja iz određene oblasti (Csikszentmihalyi, Rathunde \& Whalen 1993, prema Csikszentmihalyi et al., 2005), kao i da su matematički talentovani učenici koji su u prvoj polovini kursa iz matematike iskusili ,preplavljenost", u drugoj polovini ostvarivali bolji učinak u matematici od svojih početno „nepreplavljenih“ matematički darovitih vršnjaka (Heine, 1996, prema Csikszentmihalyi et al., 2005). Za intrinzički motivisane darovite učenike se, takođe, može reći da naginju ciljnoj orijentaciji poznatoj kao „orijentacija na zadatak“, koja, za razliku od „orijentacije na izvedbu“, počiva na shvatanju inteligencije kao promenljivog svojstva koje se može unapređivati, što korespondira sa njihovom preferencijom težih zadataka (Dweck, 2002).

No, osim saznanja da je glavna odrednica motivacije darovitih u intrinzičkoj vezi između aktivnosti učenja i njenih ishoda, temeljnije razumevanje ove problematike iziskuje i ukazivanje na različite tipove intrinzičke motivacije. Naime, na pojedinim mestima u literaturi se govori o tri glavne pojavne forme intrinzičke motivacije, a to su: intelektualna ili saznajna radoznalost, težnja ka kompetenciji ili samoefikasnosti i motiv postignuća (Lens \& Rand, 2000). Intelektualna ili saznajna radoznalost ogleda se u potrebi usvajanja i razumevanja novih informacija i najpobudljivija je u kontaktu sa umereno disonantim, složenim i novim znanjima. Naime, informacije koje su isuviše poznate i jednostavne proizvode zasićenje, dosadu i ravnodušnost, dok, sa druge strane, informacije koje su u potpunosti nepoznate i preterano složene imaju za posledicu nesigurnost i/ili odustajanje od učenja. Pojedini autori su ustanovili dihotomiju radoznalosti darovitih učenika, razlikujući „radoznalost tipa 1“, koja se pobuđuje u kontaktu sa spoljnim stimulusima sa obeležjem novine, od „radoznalosti tipa 2“, koja ima ishodište u kognitivnom disbalansu koji pokreće na učenje (Cohen, 1988). Ukoliko bismo ovaj tip intrinzičke motivacije opisali kao potrebu za procesuiranjem novih informacija, analogno tome, težnja ka kompetenciji i samoefikasnosti, kao drugi tip, mogao bi se prevesti kao potreba pojedinca za rešavanjem problemskih situacija (Malone

U radovima nekih domaćih autora ovaj termin se prevodi kao „podsticajno iskustvo“ (Palekčić, 1985). 
\& Lepper, 1987, prema Lens \& Rand, 2000). Ovaj tip intrinzičke motivacije povezan je sa izazovnim problemskim zadacima, pri čemu je važno naglasiti i to da uspeh u ovakvim zadacima jača doživljaj kompetentnosti jedino ukoliko osoba uspeh pripisuje vlastitim sposobnostima, odnosno uloženom trudu. Naposletku, motiv postignuća, koji je u tesnoj vezi sa težnjom ka kompetenciji, sadrži dve komponente: težnju ka postizanju uspeha i težnju ka izbegavanju neuspeha (Atkinson, 1964, prema Lens \& Rand, 2000). ${ }^{6}$ Da li će osoba težiti uspehu ili biti motivisana izbegavanjem neuspeha predstavlja funkciju triju faktora: a) jačine motiva za postizanjem uspeha, b) procene vrednosti uspeha, c) procene verovatnoće uspeha. Shodno tome, motiv postignuća darovitih učenika, koji se javlja u formi težnje za postizanjem uspeha, počiva na visokom vrednovanju i očekivanju uspeha, pri čemu se misli na uspeh u angažovanju na izazovnim zadacima. S obzirom da isuviše laki zadaci slabe intenzitet motiva postignuća, daroviti učenici najbolje rezultate postižu u homogenim odeljenjima u kojima je nivo zahteva usklađen sa nivoom njihovih sposobnosti (Atkinson \& O'Connor, 1963, prema Lens \& Rand, 2000).

Komponente akademske intrinzične motivacije, koja se u ovakvoj formulaciji prvi put pominje 80-ih godina prošloga veka (Gottfried, 1985, prema Gottfried, Fleming \& Gottfried, 2001), opisuju se i u nešto drugačijim terminima. Naime, akademska intrinzička motivacija se određuje kao zadovoljstvo usled bavljenja aktivnostima školskog učenja, a u svojoj osnovi sabira sledeće komponente: orijentaciju na ovladavanje novim znanjima, radoznalost, istrajnost, te ustremljenost na izazovne, teške i nove zadatke (Gottfried, 1985, 1990; Gottfried, Fleming, \& Gottfried, 1994, 1998; Gottfried \& Gottfried, 1996, svi prema Gottfried et al., 2001). Ovaj konstrukt se pokazao pozitivno povezanim sa školskim postignućem i povoljnom ocenom vlastite akademske kompetentnosti, te negativno koreliranim sa strepnjom od neuspeha, pri čemu je ustanovljena stabilnost ovih relacija u periodu od nižeg osnovnoškolskog uzrasta do adolescencije (Gottfried, 1985). U okviru ove longitudinalne studije došlo se i do saznanja da akademska intrinzička motivacija ishodi iz motivacije za kognitivnim ovladavanjem, koja se kod darovite dece javlja već na ranom uzrastu, zbog čega Gotfridova i saradnici zaključuju da ovaj oblik motivacije najverovatnije leži u srži superiorne inteligencije.

Premda se može pomisliti da koncept intrinzičke motivacije, kao svojevrsno opšte mesto u psihologiji darovitosti, teško može pokrenuti otvorene diskurse, izgleda da ipak postoje određena shvatanja motivacije darovitih koja iziskuju dodatna pojašnjenja. Naime, pojedini autori su skloni uverenju da ,žudnja za ovladavanjem" predstavlja neizostavan deo talenta, odnosno da je inherentna visokoj sposobnosti (Winner, 1996), što je komplementarno sa mnogim ranije koncepcijama darovitosti koje motivaciju proglašavaju konstituentom (a ne samo

S obzirom da se na pojedinim mestima u literaturi naglašava da motiv postignuća podrazumeva tendenciju ulaganja napora kako bi se ostvarilo nešto što pojedinac smatra vrednim i/ili čime čime će se istaći pred drugima (McClelland, 1953, prema Rot, 1994), važno je naglasiti da se intrinzička forma motiva postignuća odnosi samo na ostvarivanje vrednih ciljeva. 
kontributorom darovitosti), kao i sa pomenutim nalazima studije Gotfridove i saradnika u segmentu ukazivanja na utkanost motivacije u izuzetnu sposobnost. Ovakva stanovišta ne bi generisala veće nejasnoće jedino ukoliko bismo zatvorili oči pred fenomenom podbacivanja darovitih. Naime, ukoliko visoka sposobnost $\mathrm{u}$ određenom domenu neminovno povlači za sobom i žudnju darovitog pojedinca za njegovim ovladavanjem, gotovo je nemoguće ne zapitati se o razlozima neusaglašenosti sposobnosti i motivacije kod nezanemarljivog broja darovitih podbacivača (vrlo slična, ali mnogo opsežnija razmatranja ovog pitanja mogu se naći u Altaras, 2006).

Čini se umesnim pretpostaviti da potencijalno razrešenje ovih nedoumica možemo naznačiti unutar dva konceptualna okvira za pitanje intrinzičke motivacije. Prvi okvir bi se ticao distinkcije između pojmova ,potreba za saznanjem“ (need to know) i „motiv postignuća“ (drive to achieve) (Silverman, 1998), koja aludira na mogućnost postojanja darovitih pojedinaca koji su nesumnjivo radoznali u odnosu na sadržaje domena svog talenta, ali nedovoljno spremni na dugotrajan i naporan rad koji je preduslov uspešnog ovladavanja relevantnim područjem znanja. Ovim zapažanjima možemo pridodati i ranije pominjanu tipologiju intrinzičke motivacije koja upućuje na povezanost motiva postignuća sa težnjom ka kompetenciji i samoefikasnosti, ali ne i sa intelektualnom radoznalošću (Lens \& Rand, 2000). Dakle, intrinzička motivacija se može proglasiti neizostavnim delom talenta jedino ukoliko se pri tome misli na intelektualnu ili saznajnu radoznalost, za koju se i kaže da predstavlja „,najtipičniji oblik intrinzičke motivacije“ (Lens \& Rand, 2000, str. 198). Intelektualna radoznalost je, prema tome, zaista inherenta visokoj sposobnosti, ali nije nužno skopčana sa onim aspektom intrinzičke motivacije koji pokreće i održava naporne aktivnosti usvajanja novih znanja.

Osim što se urušenost intrinzičke motivacije kod učenika superiorne inteligencije može sagledati kroz prizmu razlučivanja njenih „saznajnih“ $i$,radnih“ aspekata, drugi konceptualni okvir koji se čini podesnim za razumevanje podbacivanja darovitih učenika počiva na poznavanju osobite vulnerabilnosti intrinzičke motivacije u populaciji darovitih (Lens \& Rand, 2000). Naime, literatura deteljno opisuje empirijski posvedočenu mogućnost promene motivacione orijentacije darovitih učenika od intrinzičke ka ekstrinzičkoj, koja se registruje na uzrastu od oko 10. godine, a koja se dovodi u vezu sa neadekvatnom implementacijom sistema eksternih nagrada u okviru tradicionalno ustrojenog školskog sistema (Harter, 1981, prema Lens \& Rand, 2000). Preciznije rečeno, intrinzičku motivaciju pouzdano možemo proglasiti neminovnom komponentom talenta samo na ranom uzrastu, kada su „darovita deca visoko motivisana za učenje i razvijanje svojih izuzetnih sposobnosti““ (Gottfried, 1990; Gottfried et al. 1994, prema Lens \& Rand, 2000, str. 198), a istovremeno su pošteđena sistematske izloženosti podrivajućem uticaju spoljnih nagrada. No, ne mora svaki pokušaj ekstrinzičkog nagrađivanja učenika koji gaji autentičan interes za nova saznanja imati „skrivene troškove“ (Deci \& Ryan, 1987, prema Reeve, 2010), odnosno rezultirati drastičnom promenom u motivacionoj orijentaciji. Preovlađujući stav nauke po pitanju mehanizma 
delovanja spoljnih nagrada na intrinzički pokrenutu aktivnost učenja mogao bi se sažeti u zapažanje da samo očekivane i opipljive (materijalne) nagrade, koje su, prema tome, egzogene u odnosu na prirodu same aktivnosti učenja, pokazuju tendenciju nadjačavanja autentičnog interesa za znanje, te uzrokuju promenu $\mathrm{u}$ lokusu kauzalnosti sa unutrašnjeg na spoljašnji (Deci \& Ryan 1985, Lapper \& Green, 1978, Luyren \& Lens, 1981, svi prema Lens \& Rand, 2000). U ovakvim situacijama, dakle, eksterne nagrade preuzimaju kontrolu nad aktivnostima učenja, postepeno urušavajući motivaciju koja ima ishodište u saznajnoj radoznalosti. Tome slično, neke skorije meta-analize istraživanja na ovu temu relativizuju podrivajuće efekte spoljnih nagrada na intrinzičnu motivaciju, ističući da ovaj odnos može poprimiti komplementarni karakter ukoliko se spoljne nagrade primenjuju tako da se minimizira njihovo kontrolišće dejstvo na ponašanje pojedinca, a intenzivira njihova informativna funkcija (pružanje informacija učeniku o uspešnosti obavljanja relevantne aktivnosti) (Eisenberger \& Cameron, 1996, prema Lens $\&$ Rand, 2000). Naime, ovako implementirane spoljne nagrade jačaju kod pojedinca doživljaj kompetentosti, što nesumnjivo rezultira narastanjem intrinzičke motivacije (Deci \& Ryan, 1985, prema Lens \& Rand, 2000). U skladu sa tim, pojedini autori zaključuju da spoljne nagrade nemaju štetan uticaj na intrinzičku motivaciju, ukoliko ne uspevaju da pokolebaju autentičan interes za znanje (Rigby, Decy, Patrick \& Ryan, 1992, prema Lens \& Rand, 2000).

Vremensku kolebljivost intrinzičke akademske motivacije beleže i istraživanja u kojima je ova varijabla bila operacionalizovana preko nastavnih interesovanja, te obuhvaćena u širokom rasponu hronoloških uzrasta. Naime, pojedina istraživanja su registrovani pad opšte akademske motivacije tokom perioda srednje škole povezivala sa neizazovnim kurikulumom i pasivizirajućom organizacijom nastave (Fredricks \& Eccles, 2002, prema Dotterer, McHale \& Crouter, 2009), odnosno nedostatkom intelektualne stimulacije za darovite učenike u okviru redovne nastave (Baker, Bridger \& Evans, 1998, Reis \& McCoach, 2000, svi prema Frederics, Alfeld \& Eccles, 2010; Csikszentmihalyi, Rathunde \& Whalen, 1993). Sa druge strane, intrinzička motivacija darovitih se pokazala lako održivom u nestrukturiranim nastavnim aktivnostima koje favorizuju fleksibilan pristup učeniku (Winner, 1996), kao i u okviru zadataka koji nadilaze nivo reprodukcije i ponavljanja (Larson, 2000, prema Fredrics et al., 2010), angažujući više mentalne procese i učenje putem rešavanja problema (Hertzog, 2003). I u nekim starijim radovima iz ove oblasti se nailazi na podatak da izostanak nastavnih izazova u okviru tradicionalno koncipiranih školskih sistema dovodi do postupnog urušavanja i gotovo potpunog iščezavanja intelektualne znatiželje kod većine učenika, već do polaska u srednju školu (Bruner, 1966, prema Lens \& Rand, 2000). Ovakvi nalazi bi mogli poslužiti kao osnova za zaključak da osim neotpornosti na intenzivne spoljne nagrade, ,slabe tačke“ intrinzičke motivacije postaju jasno uočljive i u kontaktu sa nestimulativnim sadržajima koji ne korespondiraju sa nivoom sposobnosti učenika, što je najizraženije u skupini darovitih koji su i „,najvulnerabilniji na situacione činioce koji slabe intrinzičku motivaciju“ (Lens \& Rand, 2000, str. 198). 
Kreativnost. Čini se da postoje barem tri razloga koji nameću potrebu za posebnim razmatranjem kreativnosti akademski darovitih učenika, a koji se prepoznaju na tri nivoa tumačenja relacija između kreativnosti i darovitosti. Ako krenemo od najopštijeg nivoa, dolazimo do neodređenosti pojmovnog statusa kreativnosti u okviru tzv. dualističkih koncepcija darovitosti koje, sa jedne strane, kreativnost proglašavaju nužnim sastojkom darovitosti, da bi joj na drugim mestima dodelile status tek mogućeg ishoda darovitosti. Drugo, ako suzimo fokus razmatranja darovitosti na glavna područja njenog manifestovanja, suočavamo se sa neusaglašenim shvatanjima prirode odnosa između akademske i kreativne darovitosti, otuda što pojedini autori insistiraju na jasnom razgraničavanju ovih vidova talenata (Renzulli, 2005), dok se u okviru drugih sličnih tipologija spekuliše o mogućim ukrštanjima ovih „dvaju puteva“ razvoja potencijala darovitih (Callahan \& Miller, 2005). I naposletku, ako se (akademskom) darovitošću bavimo na „najmolekularnijem“ nivou na kojem dolazimo do visoke opšte inteligencije kao jednog od nužnih konstituenata darovitosti, zatičemo nezanemarljiv korpus istraživačkih nalaza koji nude dvoznačne odgovore o odnosu kreativnosti i inteligencije. ${ }^{7}$ Jedna linija u okviru ovih istraživanja je ustanovila veoma niske korelacije kreativnosti i inteligencije, ali i istakla da ovakvi nalazi nipošto ne impliciraju uzajamnu nepovezanost ovih dvaju varijabli duž njihovog celokupnog raspona (Barron, 1961, Getzels \& Jackson, 1962, Guiford, 1967, MacKinnon, 1961, Torrance, 1962, svi prema Taylor, 2009). Naime, ova istraživanja podupiru tezu o „minimumu inteligencije“ koji je neophodan za kreativno stvaralaštvo, pokazujući da inteligencija i kreativnost ostvaruju umerenu povezanost do vrednosti količnika inteligencije od 120 , da bi se nakon ovog nivoa kreativnost pokazala relativno nezavisnom u odnosu na inteligenciju (Getzels \& Jackson, 1962; Hartmann \& Teasdale, 2004, Reynolds \& Keith, 2007, svi prema Holling \& Kuhn, 2008; Torrance, 1962, prema Taylor, 2009). Međutim, dok jedan deo istraživanja svedoči o karakterističnom odnosu kreativnosti i inteligencije koji se sa porastom globalnog količnika inteligencije iznad 120 više ne može opisivati u terminima značajne korelacije, u određenim istraživanjima ove vrste izostaje empirijska potpora za „hipotezu praga“ (Mednick \& Andrews, 1967, prema Taylor, 2009; Preckel, Holling \& Wiese, 2006, Sligh, Conners \& Roskos-Ewoldsen, 2005, svi prema Holling \& Kuhn, 2008), odnosno utire put shvatanjima koja promovišu „inverznu hipotezu praga“ (Sligh et al., 2005, prema Holling \& Kuhn, 2008). Pomenute nejasnoće neizbežno iniciraju pitanje o udelu kreativnosti u dostizanju izvrsnosti, naročito u slučaju kada izvrsnost izjednačavamo sa impresivnim akademskim rezultatima.

Osim opsežnog korpusa empirijskih nalaza koji svedoče o tome da su inteligencija i kreativnost nezavisni i samo delimično preklapajući konstrukti, suštinska

\footnotetext{
Nakon Gilfordovog upečatljive opservacije da je psihološka nauka tokom prve polovine 20. veka široko zaobilazila kreativnost, posvećujući joj se kroz svega $0,2 \%$ svojih pisanih izvora (Guilford, 1950, prema Taylor, 2009), naglo se intenzivira interes za ovu problematiku, koja je vrlo često razmatrana u relaciji sa konstruktom inteligencije.
} 
razlika između ovih fenomena dodatno je potcrtana shvatanjima da inteligencija podrazumeva adaptaciju na spoljno okruženje, a kreativnost njegovu modifikaciju i preoblikovanje (Sternberg, 1985, prema Sternberg \& O'Hara, 2000; Taylor, 1973, prema Taylor, 2009, kurziv moj). Ovakva određenja nedvosmisleno sugerišu da svaki zahtev za adaptacijom favorizuje inteligenciju, i istovremeno inhibira kreativnost. Imajući u vidu činjenicu da akademski talenat možemo shvatiti i kao naročitu sposobnost prilagođavanja na zahteve školske sredine, za očekivati je da se ova forma izuzetnosti u vrlo niskom stepenu oslanja na kreativnost. Oskudnu zasićenost akademskog talenta kreativnošću možemo očekivati i na osnovu saznanja da nastavnici uglavnom preferiraju inteligentne učenike koji konvergentno misle, u odnosu na kreativne učenike koji razmišljaju na nov i originalan način (Getzels \& Jackson, 1962, prema Hasan \& Butcher, 1966).

No, empirijska razmatranja relacija između kreativnosti i školskog uspeha generišu prilično nekonzistentne predstave o udelu kreativnosti u školskom postignuću. U pionirskom istraživanju ovog problema na uzorku američkih srednjoškolaca, koje su sproveli Gecels i Džekson (Getzels \& Jackson, 1962, prema Palaniappan, 2005), obavljeno je uzajamno poređenje školskog postignuća visoko inteligentnih učenika koji ostvaruju nezapažan učinak na testovima kreativnosti i visoko kreativnih učenika prosečne inteligencije. Dobijeni rezultati su ukazivali na podjednake domete $u$ školskom učinku ispitivanih grupa, iako je intelektualno postignuće kreativnih učenika prosečne inteligencije bilo za oko 20 IQ jedinica niže u odnosu na intelektualno postignuće nadprosečno inteligentne skupine. Značajna povezanost kreativnosti i školskog postignuća višestruko je potvrđena u brojnim drugim istraživanjima koja su sa manje ili više doslednosti replicirala ovaj nacrt (Behroozi, 1997, Edwards, 1965, Mayhon, 1966, Nori, 2002, Tanpraphat, 1976, svi prema Naderi, Abdullah, Aizan, Sharir \& Kumar, 2010; Torrance, 1962, prema Torrance, 2004; Yamamoto, 1964, prema Palaniappan, 2005; Palaniappan, 2005). Ovakvi nalazi se na nekim mestima interpretiraju kao pokazatelji mogućnosti kompenzovanja osrednje inteligencije kreativnošću (Palaniappan, 2005), premda ima i autora koji u ovakvom odnosu kreativnosti i školskog postignuća vide smernicu za koncipiranje okvira identifikacije darovitih učenika, koji bi uz ostale relevantne indikatore, nužno sadržavao i podatak o nivou kreativnosti učenika (Torrance, 2004). Ovim shvatanjima se pridružuju i autori koji ističu nesumnjivu povezanost kreativnosti i viših stupnjeva akademske uspešnosti (Bentley, 1966, Shin, \& Jacobs, 1973, Smith, 1971, svi prema Naderi et al., 2010).

Uloga kreativnosti u kontekstu akademske darovitosti nesumnjivo bi bila jasnije definisana da relevantna literatura ne skladišti i popriličan broj empirijiskih nalaza koji negiraju povezanost kreativnosti sa školskim postignućem (Ai, 1999, Edwards, 1965; Hasan \& Butcher, 1966; Mayhon, 1966, Nori, 2002, Tanpraphat, 1976, svi prema Naderi et al., 2010), odnosno upućuju na negativan predznak korelacije između učinka na testovima kreativnosti i školskog uspeha (Sierwald, 1989, prema Naderi et al., 2010). Iako ne postoji konačan odgovor na pitanje o značaju kreativnih sposobnosti u dostizanju akademske izvrsnosti, čini se smi- 
slenim pretpostaviti da su pomenute kontradikcije posledica „osetljivosti“ kreativnosti na konkretno područje znanja. Naime, na osnovu saznanja da „različita područja intelektualnog delovanja iziskuju i različit nivo kreativnosti“" (Getzels \& Csikszentmihalyi, 1972, prema Sternberg \& O'Hara, 2000, str. 611), opravdano je pretpostaviti da sadržaji različitih nastavnih predmeta u nejednakom stepenu angažuju kreativne sposobnosti učenika. Prema tome, neusaglešenost rezultata istraživanja odnosa kreativnosti i školskog postignuća mogla bi proizilaziti iz različitog složaja nastavnih predmeta koji su uzeti u razmatranje pri operacionalizovanju školske uspešnosti. Otuda je moguće zaključiti da kreativnost nije „stabilan“ konstituent akademskog talenta, već da se njena involviranost menja u funkciji specifičnog domena akademske darovitosti.

Za razliku od kvantitativnog aspekta akademske kreativnosti koji se zbog svoje kolebljivosti ne može precizno odrediti, kvalitativna priroda kreativnosti koja je utkana u visoko školsko postignuće je prilično jednoznačna. Naime, ako se pozovemo na distinkciju između ,kreativnosti koja se piše malim 'k', i kreativnosti koja se piše velikim 'k'", dolazimo do dve osnovne kategorije kreativnosti, pri čemu se prva opisuje u terminima neobičnog rešavanja problema i samostalnosti u otkrivanju pojedinih aspekata domena darovitosti, dok se druga tiče „prave kreativnosti“" koja pojedincu pribavlja etiketu eminentnosti, a dati domen upotpunjuje novim sadržajima (Winner, 2000; Winner, 2003). Drugim rečima, kreativnost dece se manifestuje na jednom nižem nivou koji još uvek ne nudi mogućnost generisanja retkih i upotrebljivih ideja, već ima predznak originalnosti u mišljenju i samostalnog otkrivanja novih saznanja, što svakako doprinosi uspehu u školskom učenju. Shodno tome, kreativnost koja je sadržana u akademskom talentu je ,kreativnost sa malim k“, koju pojedini autori nazivaju i „kreativnim prilazom učenju“ (Callahan \& Miller, 2005).

Ako se vratimo na početak poglavlja o ulozi kreativnosti u akademskom talentu i evociramo tri pomenuta nivoa poteškoća u razumevanju ove problematike, moguće je izvesti sledeća zapažanja: 1) kreativnost možemo smatrati i konstituentom i mogućim ishodom darovitosti; 2) akademska darovitost je, zbog uzrasta za koji se vezuje, jasno razgraničena od ,prave“ kreativno-produktivne darovitosti, ali sasvim izvesno sadrži ,kreativnost sa malim ' $k$ '“; 3) dok je inteligencija „stabilan“ činilac visokog školskog postignuća, kreativnost upliviše u akademsku uspešnost u meri u kojoj zahtevi konkretnog akademskog domena to zahtevaju.

\section{ZAKLJUČAK}

Iako mnogi savremeni autori ističu da darovitost „,moramo razmatrati ne samo u terminima multiplih komponenti, nego i u terminima njenih različitih tipova“ (Sternberg, 1990, prema Heller \& Schofield, 2000, str. 123), važno je imati na umu i činjenicu da se akademski talenat ponekad sreće u formi predisponiranosti za lako ovladavanje širokim rasponom nastavnih oblasti, odnosno uspešnosti u rešavanju različitih tipova problemskih situacija. No, akademski talenat mnogo 
češće podrazumeva jasnu diferencijaciju izuzetnog potencijala u kontekstu pojedinačnih područja znanja, zbog čega se o ovom fenomenu gotovo neizostavno govori kao o domenospecifičnom.

Empirijski nivo bavljenja akademskom darovitošću podrazumevao je demistifikaciju prirode ovog fenomena u nekoliko važnih aspekata. Kao prvo, istraživanja kognitivne dimenzije akademskog talenta upućuju na postojanje određenih distinktivnih karakteristika ovog fenomena koje nisu samo kvantitativne prirode, već podrazumevaju i specifičan profil sposobnosti koji korespondira sa tipom akademskog talenta. Tako, na primer, izuzetnost u domenu jezika i društvenih nauka ima uporište $u$ visoko razvijenim verbalnim sposobnostima, dok upravljenost na „kvantitativne domene“ odlikuju povišenja u apektu numeričkih i vizuospacijalnih sposobnosti. Rezultati, nadalje, sugerišu da je izuzetnim sposobnostima inherentna saznajna radoznalost $u$ odnosu na određeno područje znanja, no u nedostatku nekih drugih aspekata intrinzičke motivacije, koji se tiču posvećenosti i istrajavanja u aktivnostima učenja, izuzetna sposobnost, premda pojačana nesvakidašnjom radoznalošću, neće proizvesti impresivan akademski učinak. Takođe je važno napomenuti da motivacija akademski darovitih učenika zadržava svoj intrinzički karakter samo ukoliko je učenik dominantno izložen nastavnim sadržajima koji se percipiraju kao izazovni, kao i u dodiru sa nematerijalnim spoljnim nagradama koje imaju informativni, a ne kontrolišući uticaj. I naposletku, premda se akademski talenat u najvećoj meri svodi na prilagođavanje postojećim školskim zahtevima, akademski domeni iziskuju i izvestan stepen divergentosti u mišljenju, koja potpomaže ovladavanje školskim zahtevima.

\section{REZIME}

Visoke sposobnosti za usvajanje i sintetizovanje novih znanja vrlo retko se sreću u formi izuzetnog akademskog učinka koji se registruje u širokom rasponu nastavnih oblasti, što znači da globalna darovitost nije nemoguć, ali je redak ishod razvoja izuzetnih potencijala. Akademski talenat se gotovo neizostavno tumači i identifikuje u kontekstu određenog područja znanja, zbog čega se o njemu govori kao o domenospecifičnom fenomenu. Imajući u vidu savremena shvatanja darovitosti kao multidimenzionalnog konstrukta, istraživanja u ovoj oblasti psihologije generisala su pozamašan korpus nalaza koji pretenduju da pojasne ključne konstituente akademske darovitosti: specifične sposobnosti, motivaciju i kreativnost. Glavni zaključci koji proizilaze iz istraživanja kognitivnih aspekata akademske darovitosti upućuju na postojanje određenih distinktivnih karakteristika ovog fenomena koje nisu samo kvantitativne prirode, već podrazumevaju i specifičan profil sposobnosti koji korespondira sa tipom akademskog talenta. Rezultati, nadalje, sugerišu da izuzetan akademski učinak daroviti učenici duguju visokoj saznajnoj radoznalosti, ali isto tako potcrtavaju da u nedostatku nekih drugih aspekata intrinzičke motivacije, koji se tiču posvećenosti i istrajavanja u aktivnostima učenja, postoji mogućnost da visoki potencijali ostanu nedovoljno realizovani. 
I naposletku, premda se akademski talenat u najvećoj meri svodi na prilagođavanje postojećim školskim zahtevima, akademski domeni iziskuju i izvestan stepen divergentosti u mišljenju, koja potpomaže ovladavanje školskim zahtevima. Naime, dok je inteligencija „stabilan“ činilac visokog školskog postignuća, kreativnost upliviše u akademsku uspešnost u meri u kojoj zahtevi konkretnog akademskog domena to zahtevaju.

Jasmina Pekić

\title{
ACADEMIC GIFTEDNESS: FORMS AND EMPIRICAL BACKGROUND
}

\begin{abstract}
SUMARY
High capacity for adopting and synthesizing new knowledge very rarely encountered in the form of exceptional academic performance, which is registered in a wide range of subject areas, which means that the global talent is not impossible, but it is a rare outcome of the development of exceptional potential. Academic talents are almost invariably interpreted in relation to the specific areas of knowledge. Bearing in mind the contemporary concepts of giftedness as a multidimensional construct, research in this field of psychology have generated the large body of findings that aim to clarify the key constituents of academic talent: specific abilities, motivation and creativity. The main conclusions arising from the study of cognitive aspects of academic talent point out the relevance of specific academic abilities that corresponds to the type of academic talent. The results further suggest that the outstanding academic performance of gifted students is related to the high level of curiosity, but also underline that in the absence of some other aspects of intrinsic motivation, such as dedication and persistence in learning activities, there is a possibility that high potentials remain inadequately implemented. And finally, while intelligence is "stable" factor for high academic achievement, creativity is relevant for academic success to the extent that specific academic domains require.

Keywords: academic ability, cognitive aspect of academic talent, intrinsic motivation and creativity.
\end{abstract}

\section{LITERATURA}

Akin, C. (2005). Academic asynchrony. Gifted Child Today, 28(2), 60-65.

Altaras, A. (2006). Darovitost i podbacivanje. Pančevo: Mali Nemo.

Benbow, C. P., Stanley, J. C., Kirk, M. K. \& Zonderman, A. B. (1983). Structure of intelligence in intellectually precocious children and in their parents. Intelligence, 7, 129-152.

Benbow, C. P. \& Minor, L. (1990). Cognitive profiles of verbally and mathematically precocious students. Gifted chiled quarterly, 34 (1), 21-26.

Bloom, B. (1985). Developing talent in young people. New York: Ballantine Books.

Brody, L. E. \& Stanley, J. C. (2005). Youths who reason exceptionally well mathematically and/or verbally: Using the MVT: D4 model to develop their talents. U: R. J. Sternberg \& J. E. Davidson (Eds.), Conceptions of giftedness (pp. 20-38), New York: Cambridge University Press.

Burton, L. (1984). Mathematical thinking: The struggle for meaning. Journal for Research in Mathematics Education, 15, 35-49. 
Callahan, C. M. \& Miller. E. M. (2005). A child-responsive model of giftedness. U: R. J. Sternberg \& J. E. Davidson (Eds.), Conceptions of giftedness (pp. 38-52), New York: Cambridge University Press.

Casey, M. B. \& Brabeck, M. (1989). Exceptions to the male advantage in a spatial task: Family handedness and college major as factors identifying women who excel. Neuropsychologia, 27, 689-696.

Casey, M.B., Winner, E., Brabeck, N. \& Sullivan, K. (1990). Visual/spatial abillities in art, math and science majors: Efect of sex, family handedness and spatial experience. $\mathrm{U} \mathrm{K}$. Gilhooly, M. Keane, R. Logie \& G. Erdos (Eds.), Lines of thinking: Reflections on the psychology of thought (pp. 275-294). Oxford: John Wiley \& Sons.

Chan, D.W. (2008). Giftedness of Chinesse students in Hong Kong: percpectives from different conceptions of intelligence. Gifted Child Quarterly, 52(1), 40-54.

Chan, D.W. (2010). Developing the impossible figeres task to assess visual-spatial talents among Chinese students: A Rasch measurement model analysis. Gifted Child Quarterly, 54(1), 59-71.

Cohen, L.M. (1988). Developing children's creativity, thinking and interests: strategies for district, school, and classrooms. OSSC Bulletin, 31, 1-7.

Coleman, L.J. \& Cross, T.L. (2001). Being gifted in school: An introduction to development, guidance and teaching. Waco, TX: Purfock Press.

Cross, T.L. \& Coleman, L.J. (2005). School based conception of giftedness. U: R. J. Sternberg \& J. E. Davidson (Eds.), Conceptions of giftedness (pp. 52-63). New York: Cambridge University Press.

Csikszentmihalyi, M., Rathunde, K. \& Whalen, S. (1993). Talented teenagers: the roots of success and failure. New York: Cambridge University Press.

Csikszentmihalyi, M., Abuhamdeh, S. \& Nakamura, J. (2005). Flow. In: A.J. Elliot \& C.S. Dweck (Eds.), Handbook of competence and motivation (pp. 598-608), New York: The Guilford Press.

D’Amico, S. \& Kimura, D. (1987). Evidence for subgroups of adextrals based on speech lateralization and cognitive patterns (Reserch Bulletin No. 664). Ontario: University of Western Ontario, Department of Psychology.

Detterman, D. K. \& Daniel, M. H. (1989). Correlations of mental tests with each other and with cognitive variables are highest for low IQ groups. Intelligence, 13, 349-359.

Dotterer, A. M., McHale, S. M. \& Crouter, A.C. (2009). The development and correlates of academic interests from childhood through adolescence. Journal of Educational Psychology, 101(2), 509-519.

Dweck, C. S. (2002). Beliefs that make smart people dumb. In R. Sternberg (Ed.), Why smart people can be so stupid (pp. 42-60). New Haven, CT: Yale University Press.

Feldhusen, J.F. \& Jarwan, F.A. (2000). Identification of gifted and talented youth for educational programs. U: K. A. Heller, F. J. Mönks, R. J . Sternberg \& R. Subotnik (Eds.), International handbook of giftedness and talent (pp. 271-282). Oxford: Elsevier science.

Feldman, D. H. \& Goldsmith, L. T. (1991). Nature's gambit: Child prodigies and the development of human potential. New York: Teachers College Press.

Fox, L.H (1981). Identification of the academically gifted. American Psychologist, 36(10), $1103-1111$.

Fredricks, J.A., Alfeld, C. \& Eccles, J. (2010). Developing and fostering passion in academic and nonacademic domains. Gifted Child Quarterly, 54(1), 18-30. 
Gagné, F. (2000). Understanding the complex choreography of talent development through the DMGT- based analysis. U: K. A. Heller, F. J. Mönks, R. J . Sternberg \& R. Subotnik (Eds.), International handbook of giftedness and talent (pp. 67-81). Oxford: Elsevier science.

Gagné, F. (2005). From gifts to talents: The DMGT as a devalopmental model. U: R. J. Sternberg \& J. E. Davidson (Eds.), Conceptions of giftedness (pp. 98-120). New York: Cambridge University Press.

Gardner, H. (1993). Frames of mind: The theory of multiple intelligences. New York: Bantam Books.

Gardner, H., Kornhaber. M .L. \& Wake, W. K. (1999). Inteligencija: različita gledišta. Jastrebarsko: Naklada Slap.

George, D. (1997). The chalenge of the able child. (2nd edn). London: David Fulton Publishers.

George, D. (2003). Obrazovanje darovitih: kako identificirati i obrazovati darovite i talentirane učenike. Zagreb: Educa.

Getzels, J.W. \& Jackson, P.W. (1962). Creativity and intelligence: Explorations with gifted students. New York: Wiley.

Gottfried, A. E (1985). Academic intrinsic motivation in elementary and junior high school students. Journal of Educational Psychology,77(6), 631-645.

Gottfried. A.E., Fleming, J.S. \& Gottfried, A.W. (2001). Continuity of academic intrinsic motivation from childhood through late adolescence: a longitudinal study. Journal of Educational Psychology, 93(1), 3-13.

Gray-Fow, B. (2005). Discovering and developing talent in schools. New York: David Fulton Publisehers.

Gross, M. U. M. (2000). Issues in the cognitive development of exceptionally and profaundly gifted individuals. U: K. A. Heller, F. J. Mönks, R. J . Sternberg \& R. Subotnik (Eds.), International handbook of giftedness and talent (pp. 179-192). Oxford: Elsevier science.

Gross, M. U. M. (2005). Exceptionally gifted children (2nd ed.). New York: Routledge Falmer.

Gustin, W. \& Corazzo, L. (1994). Mathematical and verbal reasoning as predictors of science achievement. Roeper review, 16(3), 160-162.

Hasan, P. \& Butcher, H.J. (1966). Creativity and intelligence: a partial replication with scotish children of Getzel's and Jackson's study. British Journal of Psychology, 57(1-2), 129-135.

Heller, K. A. \& Schofield, N. J. (2000). International trends and topics of research on giftedness and talent. U: K. A. Heller, F. J. Mönks, R. J . Sternberg \& R. Subotnik (Eds.), International handbook of giftedness and talent (pp. 123-137). Oxford: Elsevier science.

Hermelin, B. \& O'Connor, N. (1986). Spatial representations in mathematically and in artistically gifted children. British Journal of Educational Psychology, 56, 150-157.

Hertzog, N. B. (2003). Impact of gifted programs from the students'perspective. Gifted Child Quarterly, 47, 131-143.

Holling, H. \& Kuhn, J.T. (2008). Does intellectual giftedness affect the factor structure of divergent thinking? Psychology Science Quarterly, 50(2), 283-294.

Hong, E. \& Aqui, Y. (2004). Cognitive and motivational characteristics of adolescents gifted in mathematics: Comparisons among students with different types of giftedness. Gifted Child Quarterly 4(3), 191-201.

Jackson, N.E. \& Klein, E.J. (1997). Gifted performance in young children. U: N. Colangelo \& G.A. Davis (Eds.), Handbook of gifted education (2nd edition), (pp. 460-474). Boston, MA: Allyn \& Bacon. 
Kerr, B. (2009). Encyclopedia of giftedness, creativity and talent. Thousand Oaks: Sage Publications.

Koro-Ljungberg, M. (2002). Constructions of high academic achievement through the analysis of critical events. Gifted Child Quarterly, 46(3), 209-223.

Legree, P. J., Pifer, M. E., \& Grafton, F. C. (1996). Correlations among cognitive abilities are lower for higher ability groups. Intelligence, 23, 45-57.

Lens, W. \& Rand, P. (2000). Motivation and cognition: their role in the development of giftedness. U: K. A. Heller, F. J. Mönks, R. J . Sternberg \& R. Subotnik (Eds.), International handbook of giftedness and talent (pp. 193-202). Oxford: Elsevier science.

Lewis, M. (1985). Gifted or disfunctional: The child savant. Pediatric Annals, 14(10), 733-742.

Livne, L. N. \& Milgram, R. M. (2000). Assessing four levels of creative mathematical ability in Israeli adolescents utilizing out-of-school activities: A circular Three-stage technique. Roeper Review, 22(2), 111-126.

McCoach, D. B. (2002). A validation study of the school attitude assessment survey. Measurement and evaluation in counseling and development, 35(2), 66-99.

Macoby, E. E. \& Jacklin, C. N. (1974). The psychology of sex differences. Stanford: Stanford University Press.

Miller, R. C. (1990). Discovering mathematical talent. Retrieved Septembar 7, 2006. from the World Wide Web: http://www.eric.hoagiesgifted.org/.

Naderi, H., Abdullah, R., Aizan, H.T., Sharir, J. \& Kumar, V. (2010). Relationship between creativity and academic achievement: A study of gender differences. Journal of American Science, 6(1), 181-190.

Olszewski-Kubilius, P. \& Whalen, S.P. (2000). The education and development of verbally talented students. U: K. A. Heller, F. J. Mönks, R. J . Sternberg \& R. Subotnik (Eds.), International handbook of giftedness and talent (pp. 397-412). Oxford: Elsevier science.

Palaniappan, A. K. (2005). Creativity and academic achievement: A Malaysian perspective. Shah Alam: Karis Publications.

Palekčić, M. (1985). Unutrašnja motivacija i školsko učenje. Sarajevo: Svjetlost.

Pyryt, M.C. (2000). Talent development in science and technology. U: K. A. Heller, F. J. Mönks, R. J. Sternberg \& R. Subotnik (Eds.): International handbook of giftedness and talent (pp. 427-437). Oxford: Elsevier science.

Reed, C. (2004). Mathematically gifted in the heterogeneously grouped mathematics classroom: What is a teacher to do? Journal of Secondary Gifted Education, 15(3), 89-97.

Reeve, J. (2010). Razumijevanje motivacije i emocija. Jastrebarsko: Naklada Slap.

Renzulli, J. S. (2005). The tree-ring conception of giftedness: A developmental model for creative productivity. U: R. J. Sternberg \& J. E. Davidson (Eds.), Conceptions of giftedness (pp. 246-280). New York: Cambridge University Press.

Renzulli, J.S \& Reis, S.M (2000). The school wide enrichment model. U: K. A. Heller, F. J. Mönks, R. J . Sternberg \& R. Subotnik (Eds.), International handbook of giftedness and talent (pp. 367-382). Oxford: Elsevier science.A R T

Robinson, N.M. (2005). In defense of a psychometric approach to the definition of academic giftedness. U: R.J. Sternberg \& J.E. Davidson (Eds.), Conceptions of giftedness (pp. 280294). New York: Cambridge University Press.

Root-Bernstein, R.S., Bernstein, M. \& Gamier, H. (1995). Correlations between avocations, scientific style, work habits and professional impact of scientists. Creativity Research Journal, 8(2), 115-137. 
Rot, N. (1994). Osnovi socijalne psihologije. Beograd: Zavod za udžbenike i nastavna sredstva. Salvia, J. \& Ysseldyke, J.E. (1995). Assesment in special and remedial education (6th ed.). Boston: Houghton-Mifflin.

Shavina, L. V. \& Kholodnaja, M. A. (1996). The cognitive experience as a psychological basis of intellectual giftedness. Journal for the Education of the Gifted, 20(1), 3-35.

Shea, D. L., Lubinski, D. \& Benbow. C. P. (2001). Importance of assessing spatial ability in intellectually talented young adolescents: a 20-year longitudinal study, Journal of Educational Psychology, 93(3), 604-614.

Simonton, D. K. (1984). Genius, creativity and leadership. Cambridge: Harvard University Press.

Silver, S. J. \& Clampit, M. K. (1990). WISC-R profiles of high ability children: interpretation of verbal-performance discrpancies. Gifted Child Quarterly, 34(2) 76-79.

Silverman, L.K. (1998). Through the lens of giftedness. Roeper Review, 20(3), 204-210.

Span, P. \& Overtoom-Corsmit, R. (1986). Information processing by intellectually pupils solving mathematical problems. Educational Studies in Mathematics, 17, 273-295.

Sternberg, R.J. \& O’Hara, L.A. (2000). Intelligence and creativity. U: R. J. Sternberg (Ed.), Handbook of intelligence, (pp. 611-631), New York: Cambridge University Press.

Sweetland, J.D., Reina, J.M. \& Tatti, A. F. (2006). WICC-III verbal/performance discrepancies among a sample of gifted children. Gifted Child Quarterly, 50(1), 7-10.

Štula, J. (2007). Osobine ličnosti kao činioci uspešnosti učenika srednjih škola za darovite. Magistarski rad, Filozofski fakultet u Beogradu, Odeljenje za psiholgiju.

Taylor, I.A. (2009). A retrospective view of creativity investigation. U: I.A. Taylor \& J.W. Getzels (Eds.), Perspectives in creativity (pp. 1-37). Chicago: Aldine Pub. Co.

Torrance, E.P. (2004). The role of creativity in identification of the gifted and talented. U: D.J. Treffinger (Ed.) Creativity and giftedness (pp. 79-87). Thousand Oaks: Corwin Press.

Trost, G. (2000). Prediction of exellence in school, higher education and work. U: K. Heller, F. Mönks, R. Sternberg \& R. Subotnik (Eds.), Giftedness and talent (pp.317-327). Oxford: Elsevier science.

Uguroglu, M. E. \& Walberg, H. J. (1979). Moivation and achievement: a quantitative synthesis. American Educational Reserch Journal, 16, 375-389.

Wieczerkowsky, W., Cropley, A. \& Prado, M. (2000). Nurturing talents/gifts in mathematics. U: K. Heller, F. Mönks, R. Sternberg \& R. Subotnik (Eds.), Giftedness and talent (pp. 413-425). Oxford: Elsevier science.

Wilkinson, S. C. (1993). WISC-R profiles of children with superior intellectual ability. Gifted Child Quarterly, 37, 84-91.

Winner, E. (1996). Gifted children: Myths and realities. New York, Basic Books.

Winner, E.\& Martino, G. (2000). Giftedness in non-academic domains: the case of the visual arts and music. U: K. Heller, F. Mönks, R. Sternberg \& R.Subotnik (Eds.), Giftedness and talent (pp. 95-110). Oxford: Elsevier science.

Winner, E. (2003).Creativity and talent. U: M. H. Bornstein, L. Davidson, C. L. Keyes, K. A. Moore \& L. Erlbaum (Eds.), Well-being: positive development across the life course (pp. 371-379). Mahwah, N.J.: Lawrence Erlbaum Associates.

Ziegler, A. \& Heller, K. A. (2000). Conceptions of giftedness from a meta-theoretical perspective. U: K. A. Heller, F. J. Mönks, R. J. Sternberg \& R. Subotnik (Eds.): International handbook of giftedness and talent (pp. 3-23). Oxford: Elsevier science. 